\title{
THE NECESSITY FOR FACTORY LEGISLATION IN THE SOUTH
}

\author{
By Hayes Robins \\ Dean, Institute of Social Economics, New York
}

The keynote that needs to be struck in the child labor matter, South or anywhere, is not "hands off," but hands on. It is fortunate for social progress that the point of view of modern economic thought has drifted so far away from the old-school doctrine of non-interference that we can take hold of a problem like this to some robust, practical purpose, without becoming intellectually disreputable; and the reason why this is fortunate is that right here factory legislation has met its bitterest opposition, ever since the first child labor act in England, in $I 802$.

The doctrine that cheapness is the all-sufficient goal of economic progress, the only economic fact of any possible interest or concern to the laborers, has been a corner-stone in political economy. Only within recent years has the idea begun to dawn that an adequate theory of economic welfare must include the interests of the citizen as a producer as well as a consumer; that the conditions under which the man works, and his opportunities of enjoying the fruits of his labor, are quite as vital to his happiness as the price of potatoes or beef or clothing. It is clear, now, however, that cheapness, important as it is, must come, and in the long run can only come, through more effective utilizing of natural forces, by invention and machinery, not through the overworking and social degradation of labor; and the great enlightening circumstance on this point has been the fact that the whole price-cheapening trend of our modern industrial era has come hand in hand with increasing wages, diminishing hours, and restrictions on the labor of women and children.

In respect to child labor alone, the progress of protective legislation has been extraordinary. England has had a half-time factory and school law for children of nine and over since 1844 , the half-time age having since been raised to eleven; and a fourteenyear age limit for full-day work since I 874 . In Germany the limit 
for full-day work is fourteen years, and for any factory work at all thirteen; in Holland, Belgium, France, Austria, Norway and Sweden it is twelve; in Russia fifteen, half-time being allowed from twelve up. In Switzerland it is fourteen; in Denmark fourteen, with half-time allowed from ten up; and even in Italy child labor under nine years is absolutely prohibited.

Here in the United States, at the beginning of 1899 , when the last complete compilation on the subject was made, there were limitations on child labor in thirty-four states and all the territories. To select for comparison our greatest manufacturing states, as showing most clearly the possibility of prosperity without child labor, the limit under which such labor is prohibited in Massachusetts, New York, Connecticut Illinois and Indiana is fourteen years; in Georgia no limit. In Rhode Island fifteen and Ohio fourteen, except during school vacations, and no work at all under twelve; in North Carolina no limit. In New Jersey twelve for boys and fourteen for girls; in Alabama no limit, except in mines, twelve years. In Pennsylvania thirteen; in South Carolina no limit. Happily, the tendency is moving Southward: Missouri, Maryland, Tennessee and even Louisiana now have restrictive laws; so that the section specially known as the new industrial South, the home of the Southern cotton and iron manufacturing industries, is the only place in the United States where the idea of protecting the physical, moral and educational opportunities of little children has made practically no impression in statute law.

At the outset, now, of her industrial development, the South has a unique opportunity. She can transfer to her own conditions the results of nearly all Christendom's experience in humane factory regulation, without having to suffer over again the hardships and struggles this progress has cost. I do not mean to imply that all such legislation has worked to perfection, without evasion or hardship; but the vast improvement over no legislation at all indicates the soundness of the effort and points the line of further reform. Those who have not yet even made a start ought not to be frightened out of a beginning because the others still have something more to do.

The Japanese are a case in point. They are now reported to be sending students abroad to study modern labor legislation, with the object of applying it to their own oncoming factory system at the beginning, recognizing that it is as inevitable as progress 
itself. Russia, even Russia, has already done this. Surely the new South does not need to go to school in Russia and Japan.

It seems hardly necessary to prove the importance of doing something. Bare statement of the admitted fact that children of eight to twelve, and even younger, are working in the mills through the industrial South tells the story, and ought to be sufficient. Personally, I have seen the child labor system in operation in North and South Carolina, Georgia and Alabama, and gathered some vivid impressions; have seen scores of little people working in the dust and din of the spinning-rooms, seen scores of others on their way to the mills before daylight, who would not come out until after dark, the hours of labor ranging from eleven to twelve; have been in the homes of these people and learned something of how they live and the wages they receive. For example, we brought back from the South some I 54 weekly pay onvelopes for both adults and children, collected from operatives' families in one of the best sections, and nearly roo of them are for less than $\$ 1.50$ each, per week, the average in most cases ranging from ten to thirty or forty cents a day; only older children earning the latter sums, however.

In other words, low as the wage-rates are, the actual carnings, especially of children, are much lower. This is due partly to absences, partly to constant deductions of all sorts, for faulty work, rent, money advanced, car-fare advanced to get them down from the mountains or in from the country to the mills, and what not. In forty-four out of the I 54 envelopes, these deductions exactly cancel the entire amount of wages due. Let me cite three or four specimen cases, omitting names. One envelope, repeated two or three times, shows wages for the week $\$ 1.00$, rent seventy-five cents, balance twenty-five cents; another, wages $\$$ I.20, tin cup five cents, transportation $\$ 1.15$, balance nothing; another, wages $\$ 3.00$, rent $\$ 1.40$, loan $\$ 1.00$, balance paid sixty cents; another, wages $\$$ I. 50 , transportation $\$ 1.00$, balance fifty cents; and so on.

It is impossible to state with exactness the number of children under a given age, say fourteen years, employed in Southern factories. The Federal census does not cover this point, and only one Southern state of the group under consideration - North Carolinamakes any provision for collecting and publishing industrial and labor statistics. Close approximation to the facts of the general conditions, however, is not very difficult. It appears from the 
latest report of Commissioner Lacy, of the North Carolina Bureau of Labor, that about 7,600 children under fourteen years of age were employed in $26 \mathrm{I}$ mills in that state. The Federal census bulletins on manufactures, now being issued, show the total number of employees in the cotton manufacturing industry in the five Southern states where any important amount of cotton manufacturing exists; and for North Carolina the total in I 900 was 30,273 operatives. In other words, more than one-third of the total number of operatives in the cotton mills of that state are children under fourteen years of age. In South Carolina the total number of operatives in I 900 was $30,20 \mathrm{I}$, in Georgia 18,348 , in Alabama 8,332, in Mississippi r,675, the total for the five states being 88,829 . Estimating the same proportion of child labor throughout the entire group (and this is entirely legitimate, since North Carolina conditions are even better than in some other manufacturing sections in the South), it would appear that there are more than 22,000 children under fourteen years of age in the cotton mills of these states. On this basis, it is a conservative estimate to say that at least eight or ten thousand of these children are under twelve, while the lower extreme of the age limit is down even to the almost unbelievable point of six years; the fact being well established that children as young as six to eight and nine years are to-day working in some of the Sorthern mills.

Remember, along with this, the fact just observed in the case of our Northern states and European countries, where legislation on child labor exists, that fourteen years is very nearly the average age under which factory labor is prohibited altogether. In other words, the absence of any restrictions in the South means that fully one-third of all the operativis are younger than the age standard established by the forces of humanitarian opinion and wise statesmanship throughout the larger part of Christendom.

The amounts earned by the children in Southern mills would not be necessary to the support of the families under any proper system of factory regulation. The economics of the situation would inevitably take care of that. If the labor of the children is not available, the mills must employ older help, and in order to get such help must pay wages sufficient to maintain the families, including the children. This is how the matter has adjusted itself wherever child labor has been restricted, and of economic necessity it must be so. The difference in labor expense involved has never 
yet been sufficient to hamper industrial activity or drive capital away from any industrial section, and, so long as competing groups are not permitted to gain a permanent advantage by the wholesale use of child labor, it never will.

The lack of restrictions on child labor makes possible also that semi-barbarous institution of night work. Where all the family work by turns in the mill, the results are shockingly demoralizing. Just as a side-light on one phase of this system, let me quote a paragraph from a discussion of factory evils in the South, just published this month, by Rev. J. A. Baldwin, of Charlotte, N. C., a special student of these problems. Where part of the family work by day and part by night, he says:

"The mother has to get up at 4:30 in the morning to get breakfast for the day hands, so they can be at the mill at six; then the night hands come and eat about seven. She has to have dinner for the day hands strictly at twelve. The night hands get up and eat from four to five, so as to be ready to go to work for the night at six; she also gives them a lunch to be eaten at midnight. Then the day hands get out at six and have supper about seven. Besides this, there is house-cleaning, washing and ironing, sewing, and often the care of little children. . . . The mills usually run sixty-six hours per week at night; that is, the operatives work twelve hours from Monday night to Friday night inclusive, and on Saturday get up about two o'clock (before they have had enough sleep) to go to work at three. They then work till nine, at night. As a matter of fact it is usually ten or eleven when they get out.

"Night work is much worse in summer than in the winter. In the winter they go to bed, cover up and sleep soundly. In summer it is difficult to sleep on account of light, heat, flies and noise. In summer, while they usually go to bed, it is a very familiar sight to see them lying across the bed with their workclothes on, or on a pallet in the passage or on the porch. Their sleep is fitful and unsatisfying, and they never feel bright and fresh from the beginning to the end of the week. They furnish the most favorable conditions for the development of physical, intellectual and spiritual disease germs."

The children of factory families in the South to-day have no protection against this. Night work for women and children ought to be absolutely prohibited. It is, almost everywhere else, even in Russia. This would practically force either the employ- 
ment of men only in night work, or else its abolition altogether. I would not deny that there may sometimes be good economic reasons for night work, at least in rush times, but it should be done by men if at all, never by women and children.

Nobody is urging any step that threatens to destroy Southern mill profits, but it must be insisted that there is another way to secure profits than the way of using child labor. Scientific improvement of industrial methods is the only sure and safe road to permanent prosperity, and it would not seem that the South has much to fear when the great bulk of the most prosperous industry in Christendom is being conducted under more or less advanced forms of factory regulation. Furthermore, nobody need or ought to urge legislation as the remedy on the ground that Southern manufacturers are all indifferent and inhumane. Legislation is urged simply because it is the most uniform and least costly method the South could of its own accord adopt. Southern manufacturers are no more types of hardhearted callousness than are manufacturers anywhere; they have all been opposed to factory legislation at one time or another, under the influence of mistaken economic doctrines. I do not know, but would risk it, that scores of Southern manufacturers would be glad to see these evils abolished in their own mills if they could do it without immediate competitive disadvantage with all the rest. Here comes in the advantage of legislation, that by establishing the same conditions and opportunities for all, it imposes no special relative handicap on any.

Moreover, and here is one of the saddest features of all, the fathers, sometimes even the mothers, are among the worst offenders in this whole matter. I have seen cases, and there are others in abundance, where the wife and children practically earn the family living in the mill, while the father thoughtfully carries in the dinner-pail at noon, perhaps working a little on odd days when he gets tired of loafing. We cannot altogether blame the manufacturers when these people are fairly urging them to take on the children in the mills; and we need to remember also that to Inost of these unfortunate people factory life is a distinct improvement over the log-cabin, salt pork and peach brandy, white-trash and Georgia-cracker type of life from which many of them were sifted out when the mills came. The manufacturer knows this, and it is not surprising that he should even think himself something of a philanthropist, just in furnishing mill jobs on almost 
any terms. He does not see as yet that when these people drift down into the factory centres they become industrial, social and political factors in an altogether new and more serious sense than they ever could be while burrowing in the mountain sides.

To have practically all of the next generation of factory operatives growing up stunted in body and mind, and nearly all of them illiterates, in a section of the country where the general average of illiteracy is already appalling, is a matter of the gravest concern. Southern manufacturers sooner or later will have to recognize this fact, and its impending consequences. According to the rgoo census statistics just appearing, the proportion of illiteracy among males of voting age, white and black together, was, in Alabama 33.7 per cent, in Georgia 3 I.6 per cent, in Mississippi 33.8 per cent, in North Carolina 29.4 per cent, in South Carolina 35. I per cent; as compared, for instance, with 6.4 per cent in Massachusetts, 6.8 per cent in Connecticut, 9.2 per cent in Rhode Island, 5.9 per cent, in New York, 6.9 per cent in New Jersey, 7.7 per cent in Pennsylvania. The South simply cannot afford to permit the processes to go on that are adding fresh groups every year to its grand total of illiterate and unfit citizens. In the face of the present situation, if a new race of degenerates, brought up in exhausting toil, dense ignorance, and exposed to all the temptations of an unprotected environment, is to be developed now in the fastgrowing centres of the new South, they are certain to form a social and civic and economic menace to the community.

This will be true not only of the South; the matter is coming to have a national significance. W'ithin the limits of any one interdependent industrial group, like the United States, there must be at least some general approach to uniformity in the working conditions of the laborers, by given lines of industries. Differences in competitive success must come from differences in managing ability, quality of plant, or natural environment, not from different standards of decency in the use of labor. If long hours and child labor become the fixed conditions of success, the whole field of competing industry must eventually come down to that basis. A competitive influence which works for the undermining of higher standards of living, wherever established, is a matter of universal concern. In a democracy, no condition is safe which offers a competitive advantage to anything that leads toward ignorant, inferior citizenship. It is not safe anywhere, whether in 
Southern mill villages or Northern city slums, because to make degradation profitable in any quarter sets the current of tendency that way, with demoralizing effect.

That is why it is not meddlesome interference for American citizens not of the South to have a concern about this matter, from the broad standpoint of national welfare. The real test-point of permanent progress and prosperity, affecting the nation as well as the South, is not the size of profits in Southern mills in the next five years, large as we hope they may be through all proper means; but it is the quality of Southern citizenship in the next five generations. That citizenship is now in the making, and now is the time of times to safeguard its development. Such action will be good economics, good morals, good humanity. For the South, it is an inspiring opportunity. 